\title{
Diyabetli Bireyler için Makro Besin Ögeleri Dağılım Oranları Ne Olmalı?
}

\author{
What Should be the Macronutrients Distribution Range for People with Diabetes?
}

\section{Ceren Yolaçan İşeri ${ }^{1}$}

Geliş tarihi/Received: 25.07.2019 • Kabul tarihi/Accepted: 05.11.2019

\section{ÖZET}

Tıbbi beslenme tedavisi, diyabet yönetiminin temel bileşenlerindendir. Kan glukozunu, kan yağlarını, kan basıncını hedef aralıkta tutmaya yardımcı olur, sağlıklı vücut ağırlığının sürdürülmesini sağlar, diyabete bağlı gelişebilecek akut ve kronik komplikasyon riskini azaltır. Uzun yıllardır diyabet tedavisi için ideal olan makro besin ögeleri oranları sorgulanmakta olup yapılan çalışmalar pek çok farklı beslenme müdahalesinin tedavide etkili olabileceğini göstermektedir. Ancak, bireyler eski beslenme alışkanlıklarına dönme eğiliminde olduklarından, uzun süreli, uygulanabilir bir beslenme modeli oluşturabilmek için, makro besin ögeleri oranına odaklanmaktan vazgeçilmelidir. Tedavi hedefleri bireye özgü değerlendirilmelidir. Diyabetlinin tercihlerine uygun, sürdürebileceği bir tıbbi beslenme tedavi planı oluşturulmalı, kanıta dayalı sınırlandırmalar yapılmal, fakat yeme zevkinden mahrum edilmemelidir.

Anahtar kelimeler: Tıbbi beslenme tedavisi, makro besin öğeleri, düşük karbonhidratlı diyet, yüksek proteinli diyet

\begin{abstract}
Medical nutrition therapy is one of the key components of diabetes management. It supports to achieve blood glucose, blood lipids and blood pressure goals, maintains healthy body weight and decreases complication risks as well. It is fact that macronutrients ratio, which are ideal for diabetes treatment, have been researched for many years, studies introduce that many different nutrition interventions will be effective in this treatment. However, since individuals trend to return to their old dietary habits, focusing on the proportion of macronutrients should be abandoned in order to establish a long-term suitable diet model. Treatment goals should be evaluated individually. A sustainable treatment plan has to be composed according to diabetic's choices; evidence-based limitations have to be applied; however, their pleasure of eating has to be maintained.
\end{abstract}

Keywords: Medical nutrition therapy, macronutrients, low carbohydrate diet, high protein diet

\section{GİRIŞ}

Tıbbi beslenme tedavisi (TBT), diyabet yönetiminin temel taşlarından biridir. Diyabetli yetişkinlerde TBT’nin amacı kan glukozu, kan lipitleri, kan basincı hedeflerine uygun yeme alışkanlığı kazandırmak, sağlıklı vücut ağırlığını sağlamak veya sürdürmek, diyabete bağlı gelişebilecek komplikasyonları

önlemek, ertelemek, besin seçiminde kanıta dayalı kısıtlamalar yaparken bireyin tercihlerini, alışkanlıklarını göz ardı etmemek ve kişiyi yeme zevkinden mahrum etmeden hayat boyu sürdürebileceğibir beslenme programı oluşturmaktır (1).

1. İletişim/Correspondence: Ceren İşeri Beslenme Danışmanlı̆̆ı, İstanbul, Türkiye E-posta: info@cereniseri.com • ๑ https://orcid.org/0000-0001-7070-0895 
Yapılan pek çok çalışma, tercihen diyabet konusunda deneyimli bir diyetisyen tarafindan verilen beslenme eğitimin, HbA1c düzeylerinde tip 1 diyabetlilerde \%1-1.9, tip 2 diyabetlilerde \%0.3-2 arasinda azalma sağladığını göstermektedir (2-10). Örneğin yeni tanı almış ve HbA1c düzeyi \%9 olan bir diyabetli bireyde bu düşüş \%2'yi bulurken, yine yeni tanı almış HbA1c düzeyi \%6.6 olan bir başka diyabetlide bu oran \%0.4 civarındadır (4). Uzun süre önce tanı almış, glisemi regülasyonu kötü olan bir diyabetlide ise TBT ile HbA1c düzeyinde \%0.5'lik bir azalma sağlanabilmektedir. TBT ile glisemik kontrolde sağlanan bu iyileşme diyabetli bireyin sağlık harcamalarının azalmasında glisemik regülasyonu sağlamak amacıyla tedaviye bir ilacın eklenmesi kadar etkilidir (11).

Tıbbi beslenme tedavisi düzenlenirken, cevaplanması gereken önemli sorulardan biri, metabolik kontrolü iyileştirmekte kullanılacak yeme modelinde makro besin ögeleri için ideal bir oranının olup olmadığıdır. Tip 2 diyabette, diyet kompozisyonunun postprandiyal ve diurnal glukoz dalgalanmalarında rol oynadığı ve makro besin ögeleri kompozisyonunu değiştirmenin postprandiyal glisemiyi düşürebileceği bildirilmektedir (12). Glisemik kontrolün önemli bir parçası olan postprandiyal hipergliseminin kontrol altına alınması, HbA1c'nin düşürülmesi, mikro ve makro komplikasyonların azaltılması açısından önemlidir $(13,14)$.

$\mathrm{Bu}$ derlemenin amacı diyabetli bireylerde tıbbi beslenme tedavisi yaklaşımında makro besin ögelerinin dağılımının nasıl olması gerektiği irdelenecektir.

\section{Makro Besin Ögeleri Oranları}

\section{Karbonhidratlar}

İnsülinin keşfedilmeden önce günde 400-500 kkal enerji sağlayan açlık diyetleri veya karbonhidrat (KH) alım oranının günlük enerji alımının \%2'sini karşılayacak kadar kısıtlandığı ve enerjinin yağlardan sağlanan oranının \%70’lere çıkarıldığı diyetler tercih edilmekteydi. Bu diyetlerle tip 1 diyabetliler birkaç yıl yaşatılabilmekteydi. İnsülinin keşfinden sonra ise KH oranı \%35-40'a kadar arttırılmıştır (15). 1970’lerin sonunda özellikle diyabetlilerde kardiyovasküler (KV) ölüm görülme sıklığını göz önünde bulundurularak, total yağ ve doymuş yağ alımını azaltma önerisi getirilmiş, yağ alımı yaklaşık \%10 azaltılmış böylelikle tüketilecek KH miktarı \%10 artmış yani günlük enerji gereksiniminin \%55-60’ını karşılayacak düzeye kadar çıkartılmıştır (16).

Günümüzde düşük KH’li diyetlerle, yüksek KH’li diyetlerin etkilerini karşılaştıran pek çok çalışma literatürde yer almakla birlikte özellikle diyabet kontrolü ve sağlıklı vücut ağırlığı için ideal olan KH oranının ne olması gerektiği halen sorgulanmaktadır (17). Tüketilen KH miktarı ve endojen/eksojen insülin, postprandial kan glukozunun temel belirleyicisi olduğundan öğün planlaması yaparken tüketilecek $\mathrm{KH}$ miktarına dikkat edilmesi gereklidir. İdeal $\mathrm{KH}$ oranını belirlerken kullanılabilecek en etkili yöntem, öğünlerde tüketilen $\mathrm{KH}$ miktarı ve postprandial glisemik yanıtın izlenmesidir $(1,14)$.

Diyabet Kontrolü ve Komplikasyonları Çalışması (Diabetes Control Complication Trial [DCCT]) kapsamında, 5 ylllık süre içinde, 532 diyabetli bireyin makro besin ögelerinden sağladıkları enerjinin günlük enerji alımını karşılama oranları ile glisemik kontrol sonuçları karşılaştırılmış, yüksek KH (\%56) alan grubun HbA1c düzeyi \%7.1 bulunurken, düşük $\mathrm{KH}$ (\%37) alan grubun HbA1c düzeyi \%7.5 bulunmuştur (18). Diğer bir çalışmanın bulgularına göre ise düşük KH'li (\%46), doymuş yağ ve toplam yağ oranı yüksek (\%37) olan diyet ile yüksek KH’li (\%50), düşük yağlı (\%34) diyet kıyaslandığında düşük KH'li diyet daha kötü glisemik kontrolle ilişkili bulunmuştur (19).

Enerjinin KH'dan sağlanan oranını azaltıp doymamış yağ asitlerinden zengin, doymuş yağdan fakir bir diyet düzenlemenin lipit profilinde, kan glukozu kontrolünde ve diyabet için kullanılan ilaçların azaltılmasında daha etkili olduğu gösterilmiştir (17). Düşük KH'li diyetlerin, düşük yağlı yüksek KH'li beslenme modeline alternatif bir yöntem olarak değerlendirilebileceği ileri sürülmektedir $(1,20)$. 
Yapılan çalışmalara katılan diyabetli bireylerin heterojen olması farklı HbA1c düzeyine sahip olmaları, çalışmalarda kontrol diyetlerinin birbirinden farklı olması, çalışmalar arasında metodolojik çelişkilerin olması, örneklem sayısının az olması uzun süreli sonuçların olmaması diyet modelleri arasında karşılaştırma yapmayı oldukça zorlaştırmakta ve bir diyetin diğerinden üstün olması ihtimalini ortadan kaldırmaktadır (21).

Amerika'da yaşayan diyabetli bireylerin $\mathrm{KH}$ alımı değerlendirildiğinde günlük enerjinin \%44-46’sını KH'lardan sağladıkları bildirilmektedir. Bu bilgiler ışığında Amerikan Diyabet Birliği (American Diabetes Association [ADA]) bireylerin eski alışkanlıklara dönmeye meyilli olduklarını, bu nedenle uzun süreli bir beslenme modeli oluşturabilmek için diyabetli bireylerin var olan alışkanlıklarına benzer bir makro besin ögesi dağılımı sağlamanın esas olduğunu vurgulamaktadır (1).

Diyabetli bireyin tedavi hedefleri de göz önünde bulundurulduğunda, iyi sağlık için, sebze, meyve, tam tahıl, baklagil ve az yağlı süt ürünlerinden gelen KH'ların tercih edilmesi, yağ, şeker ve sodyum ilave edilmiş $\mathrm{KH}$ tüketiminin azaltılması doğru bir yaklaşımdır $(1,14)$.

\section{Glisemik İndeks ve Glisemik Yük}

Kanita dayalı tedavi rehberlerinde, yüksek glisemik yüklü besinleri düşük glisemik yüklü besinler ile değiştirmenin glisemik kontrolde iyileşme sağlayabildiği (1) ve tek başına $\mathrm{KH}$ alımı söz konusu olduğunda, glisemik indeksi dikkate almanın glisemik kontrole ek fayda getirebileceği ifade edilmektedir $(1,14)$. Amerikan Diyabet Birliği (American Diabetes Association [ADA]), Kanada Diyabet Cemiyeti (Canada Diabetes Association) gibi pek çok kuruluş, diyabetli bireyin eğitim süresince glisemik indeks ve glisemik yük hakkında bilgilendirilmesini önermektedir $(22,23)$.

Glisemik indeks ve glisemik yükle ilgili meta analiz sonuçlarına bakıldığında dört haftadan uzun süren, düşük glisemik indeksli diyetlerde HbA1c düzeylerindeki azalmanın daha belirgin olduğu (24) ve glisemik yükün azaltılmasının HbA1c düzeylerinde \%0.2-0.5 azalma sağlayabildiği görülmektedir $(25,26)$. Glisemik indeks ve glisemik yükün vücut ağırlık kaybından bağımsız, belirgin bir etkisinin olmadığı rapor edilmektedir (1). Ancak glisemik indeks ve glisemik yükle ilgili çalışma sonuçlarının posa tüketiminden bağımsız olarak değerlendirilmesinin doğru olmayacağı çünkü bu çalışmalarda düşük glisemik indeksli veya glisemik yüklü diyetlerin aynı zamanda yüksek posa içerdiği vurgulanmaktadır (27).

\section{Posa}

Diyabetlilerde, çözünebilir posa müdahalesinin HbA1c ve açlık kan glukoz düzeylerine olumlu etkisi olduğunu gösteren çalışmalar bulunmaktadır (28,29). Doygunluğu arttırdığı (22), gastroinstestinal geçiş süresini uzattığı ve kan glukoz düzeylerinin regülasyonunu olumlu yönde etkilediği (23) göz önüne alınarak diyet posasının arttırılması önerilmektedir (16).

Diyabetli bireylere verilen posa ve tam tahıl tüketimine ilişkin öneriler genel popülasyona verilen önerilerle aynıdır. Her 1000 kkal enerji alımı için 14 g veya kadınlar için günde $25 \mathrm{~g}$, erkekler için günde 35 g posa tüketimi idealdir (1). Eğer tolere edilebilirse, günde $50 \mathrm{~g}$ veya daha fazla miktarda posa tüketiminin, glisemiyi iyileştirdiği, preprandiyal glukoz, postprandiyal hiperglisemi ve HbA1c düzeylerinde hafif düşme sağladığı rapor edilmiştir (30). Sadece posanın glisemik regülasyona etkisini görmek oldukça zordur. Günlük $50 \mathrm{~g}$ posa alım düzeyine erişebilmek için sebze, meyve, tam taneli tahıllar, yağlı tohumlar ve baklagiller gibi işlem görmemiş besinlerden gelen posanın tercih edilmesi veya ihtiyaç varsa psyllium, dirençli nişasta ve beta-glukan ile posa takviyesi önerilmektedir (31). ADA, 50 g üzerinde posa alımını gerçekçi olmayacak biçimde yüksek bulmakta ve böyle bir öneri getirmemektedir (29). Posanın KV hastalık risk faktörlerine etkisi de karışıktır ama genellikle doğal kaynaklardan posa alımının, serum kolesterolü ve kan basıncı gibi diğer risk faktörlerini olumlu etkilediği bilinmektedir $(27,32)$. 
Hemşire Sağlık Çalışması (Nurses' Health Study [NHS]) sonuçlarına göre, tip 2 diyabetlilerde tam tahıl tüketiminin, azalan mortalite ve KV hastalık ile ilişkili olduğu belirlenmiştir (33). Genel popülasyona olduğu gibi, diyabetli bireylere de tahıl tüketiminin yarısının tam tahıllardan sağlanması önerilmektedir $(27,32)$. Glisemik kontrolü sağlayabilmek için glisemik indeksi düşük, posadan zengin, eklenmiş şeker içermeyen veya az miktarda içeren $\mathrm{KH}$ tüketiminin sağlanması yani KH kalitesi önemlidir (21).

\section{Sukroz}

Sukroz içeren besinler, yeme planında diğer izokalorik besinlerle yer değiştirebilir (1-3) fakat diyabetlilerde de genel popülasyonda olduğu gibi kardiyometabolik risk profili ve vücut ağırlık artışına olumsuz etkileri göz önünde bulundurulmalıdır (14). Ayrıca, sukroz, glukoz veya yüksek fruktozlu mısır şurubu gibi enerji değeri olan tatlandırıcıların tüketiminden sakınılmalı veya miktarları sınırlandırılmalıdır (1).

Diyabetli çocuk ve yetişkinlerin, rafine $\mathrm{KH}$ ve ilave şeker içeren meyve suları, buzlu çaylar, enerji içecekleri (28), az yağlı veya yağsız fakat şeker ilave edilmiş ürünlerin alımını azaltması bunların yerine sebze, meyve, baklagil, tam tahıl, şeker ilavesiz süt ürünleri gibi $\mathrm{KH}$ kaynaklarını tercih etmesi gerektiği bildirilmektedir $(1,14,30)$.

Dünya Sağlık Örgütü (Word Health Organization [WHO]), yaşam boyu şeker tüketiminin azaltılmasını, çocuklarda ve yetişkinlerde tüketim düzeyinin toplam enerjinin \%10'unun altında tutulmasını ve ilerleyen dönemde bu oranın \%5'inin altına düşürülmesini önermektedir. Şeker yerine enerji içermeyen tatlandırıcıların kullanılması toplam enerji alımını ve vücut ağırlığını azaltmak, glisemik kontrolü iyileştirmek için etkilidir (1,29).

\section{Fruktoz}

Besinlerle alınan serbest fruktoz, izokalorik sukroz veya nişasta ile kıyaslandığında, yavaş sindirilmesi ve emilmesi sebebiyle (29) daha iyi glisemik kontrol sağlamakta ve toplam enerjinin \%12'sini geçmediği takdirde plazma trigliserit düzeyleri üzerinde olumsuz bir etkiye sebep olmamaktadır (27).

Diyabetlilerin araştırma kapsamına dahil edildiği çok sayıda çalışma olmasa da fazla kilolu ve obez bireylerde yüksek fruktozlu mısır şurubunun fazla miktarda tüketilmesinin, viseral yağ deposu, lipit metabolizması, kan basıncı, insülin duyarlılığı ve denovo lipogenezi olumsuz etkilediği göz önünde bulundurulmalıdır (21).

Yüksek fruktozlu mısır şurubu veya sukroz içeren diyetler karşılaştırıldığında plazma açlık kan glukozu, insulin, leptin, ghrelin düzeyleri ile enerji ve mikro besin ögeleri alımı yönünden anlamlı fark olmadığı görülmektedir (34). Bu durumda metabolik anomaliye sebep olan yüksek fruktozlu misır şurubunun da tüketiminin sınırlandırılması önerilmektedir (21).

\section{Protein}

Günlük enerji alımının proteinlerden karşılanma oranına yönelik olarak diyabetli ve böbrek hasarı olmayan kişilerde glisemik kontrolü optimize edecek veya $\mathrm{KV}$ risk faktörlerini olumlu etkileyecek ideal bir oran önerisi olmadığından, hedefler bireyselleştirilmelidir (27,32).

Diyabetli ve diyabete bağlı böbrek hastalığı gelişmiş, persistan albuminürinin $30 \mathrm{mg} / 24$ saat üzerinde olduğu bireylerde; protein alımının 0.8-1 g/kg/gün altında olması önerilmez. Protein alımının daha da azaltılması albuminüriyi azaltabilmekte fakat glomerül filtrasyon hızındaki (GFR) azalmanın seyrini veya KV risk göstergelerini iyileştirmemektedir (14).

Diyabet Kontrol ve Komplikasyon Çalışması (Diabetes Control and Complication Trial [DCCT])'inda bildirildiği gibi diyabetli bireyde kan glukoz kontrolü, renal yetmezliğin önlenmesinde protein kısıtlamasından daha etkilidir. Üstelik uzun süreli protein kisitlamasinin malnutrisyona sebep olabileceği ve malnutrisyonun da tek başına renal yetmezlik progresyonunu arttırabileceği göz ardı edilmemelidir (35). 
Sağlıklı bireylerde protein yükünü oluşturan, ileri glikasyon son ürünleri (Advanced Glycation End Products [AGE]) yüksek olan diyetlerin renal hemodinamik değişikliklerden sorumlu olabileceği düşünülerek, diyabetik nefropatiden korunmak için AGE içeriği yüksek besinleri azaltmanın tercih edilebilecek yollardan biri olduğu bildirilmektedir (36).

Böbrek hastalığı olmayan, tip 2 diyabetli yetişkinler için de protein kısıtlaması önerilmemektedir. Özellikle kötü kontrollü ve yaşlı diyabetlilerde yetersiz protein alımı ve direnç egzersizi yapılmaması kas kaybını hızlandırmakta ve ciddi sarkopeniye sebep olmaktadır (16). Yine fazla kilolu ve enerjisi kısıtlanmış diyet yapanlarda, ideal protein yüzdelerine uyulamaması yetersiz protein alımına ve kas kaybına neden olabilmektedir (29).

İyi kontrollü tip 2 diyabetli bireylerde protein alımını arttırıp,KHalımınıorta düzeydeazaltmak, postprandial hiperglisemide ve insülin hipersekresyonunda anlamlı bir azalma sağlayabilmektedir. Düşük $\mathrm{KH}$ (\%31), yüksek protein (\%29), yüksek yağ (\%40) içeren diyet, $\% 54 \mathrm{KH}, \% 16$ protein, \%30 yağ içeren geleneksel diyet ile karşılaştırıldığında postprandiyal glukoz düzeyinde $\% 14$, plazma insülin düzeyinde \%22, glukoz bağımlı insülinotropik polipeptid düzeyinde $\% 17$ azalma, glukagon düzeyinde $\% 33$, kolesistokinin düzeyinde \%24, tokluk skorunda \%7 artış sağlamaktadır. Araştırmacılar, bulguların postprandiyal hiperglisemiyi tedavi etmede, bu beslenme modelinin ilaç dışı bir yaklaşım olarak kullanılıp-kullanılamayacağı sorusunu akla getirdiğini bildirmektedir (37).

Yapılan epidemiyolojik ve klinik çalışma sonuçları incelendiğinde, protein alımını arttırıp, $\mathrm{KH}$ alımını azaltmak, uzun süre doymuş yağ asitlerinden zengin besinlerin tercih edilmesine ve insülin direncinde artışa sebep olabilmektedir (30). Doymuş yağların, tekli doymamış yağlarla yer değiştirmesinin, insülin direnci ve tip 2 diyabeti olan bireylerde insülin yanıtını iyileştirebileceği, yüksek proteinli diyetlerle alınan yağ örüntüsünün dikkatle değerlendirilmesi gerektiği vurgulanmaktadır (1).

\section{Yağlar}

Diyabetli bireyler için diyet ideal yağ oranının ne olması gerektiğini gösteren öneriler yoktur. Metabolik hedefler ve KV hastalık riski de göz önünde bulundurulduğunda, yağ kalitesinin yağın miktarından daha önemli olduğu söylenebilir (27). Özellikle tip 2 diyabetli bireylerde Akdeniz tipi beslenme modeline uygun, tekli doymamış yağ asitlerinden zengin diyetin glisemik kontrolü ve/ veya serum lipit düzeylerini iyileştirdiği düşünülerek doymuş ve trans yağlar yerine doymamış yağları seçmek ve vücut ağırlığında azalma sağlamak, sağlanan vücut ağırlık kaybını korumak amacıyla yağ alımını azaltmak konusunda tavsiyelerde bulunulabilir $(27,30,32)$.

Yapılan bir çalışmada enerji alımı 200-300 kkal kısıtlanmış, tekli doymamış yağ asitlerinden zengin, \%45 KH, \%15 protein içeren diyet ile yüksek KH’li (\%60 KH, \%15 protein) diyet karşılaştırıldığında, her iki diyetin de vücut ağırlığı, vücut kompozisyonu, kardiovasküler risk faktörleri ve glisemik kontol üzerinde olumlu etkisi olduğu saptanmıştır (38). Araştırmacılar, yüksek tekli doymamış yağ alımının olumsuz etkilerinin olmaması nedeni ile geleneksel düşük yağlı diyetlere sağlıklı bir alternatif olabileceğini, diyete uyumu artırabileceğini ve hastalık riskini azaltabileceğini bildirmişlerdir (38).

Diyabetli bireylere, genel popülasyonda olduğu gibi haftada en az iki gün, 2 porsiyon yağlı balık tüketmeleri önerilmektedir $(1,27,32)$. Uzun zincirli çoklu doymamış omega-3 yağ asitlerinin glisemik kontrol üzerindeki etkisi yetersiz olmakla birlikte tip 2 diyabette lipit profilini iyileştirmekte, platelet agregasyonunu modifiye etmekte ve KV hastalıktan koruyucu etki göstermektedir (16). Yağlı balık, bitkisel yağlardan gelen uzun zincirli çoklu doymamış omega 3 yağ asitleri (kanola yağı, mısır) ve ceviz tüketiminin desteklenmesinin tip 2 diyabetlilerde KV mortaliteye karşı koruyucu olduğu bildirilmektedir (39). Yapılan 
çalışmaların, omega-3 içeren takviyelerin alınmasının KV olaylardan korunmada veya tedavisinde etkili olmadığını gösterdiği bildirilmektedir $(1,16)$.

\section{Yeme modelleri}

Düşük KH’li Akdeniz diyeti (\%35 düşük glisemik indeksli KH, \%45 yağ-doymamış yağ içeriği yüksek, \%15-20 protein), geleneksek Akdeniz diyeti (\%50-55 düşük glisemik indeksli KH, \%30 yağ-tekli doymamış yağ içeriği yüksek, \%15-20 protein) ve ADA 2003 yllı beslenme önerileri (\%50-55 KH, \%30 yă̆ ve \%20 protein) karşılaştırıldığında, düşük KH’li Akdeniz diyetinin ADA'nın önerilerine klyasla HbA1c ve düşük dansiteli lipoprotein (low density lipoproteinLDL) kolesterol düzeylerinde daha fazla azalma sağladığı, trigliserit düzeylerindeki azalmanın ve HDL kolesterol düzeylerindeki artışın geleneksel Akdeniz diyeti ve ADA önerilerine kıyasla daha fazla olduğu saptanmıştır. Beslenme müdahalesinin, her grupta KV risk faktörlerini azalttığı, düşük KH’li Akdeniz diyetinin, diğer yeme modellerinden daha etkili olduğu bildirilmiştir (40).

\section{SONUÇ VE ÖNERİLER}

Diyabetli bireyler için enerjinin makro besin ögelerinden karşılanma oranları ile ilgili tek bir ideal orandan veya tek tip bir beslenme modelinden bahsetmek mümkün değildir. Tedavi hedefleri bireye özgü değerlendirilmelidir. Hedefler, uygulanabilir ve ulaşılabilir olmalı, diyabetli birey ile işbirliği yapılarak belirlenmelidir.

Optimal sağlık için, KH kaynağı olarak sebze, meyve, tam tahıl, kurubaklagil ve az yağlı süt ürünlerinin tercih edilmesi, yağ, şeker ve sodyum ilave edilmiş besinlerin tüketiminin azaltılması kardiyometabolik risk profili ve vücut ağırlık artışına olumsuz etkileri olan sukroz, glukoz ve yüksek fruktozlu misır şurubu gibi enerji değeri olan tatlandırıcıların tüketiminden sakınılması veya miktarların sınırlandırılması, böbrek hasarı gelişmiş olsun veya olmasın protein gereksiniminin bireyselleştirilmesi, metabolik hedefler ve KV hastalık riski göz önünde bulundurularak tüketilen yağın miktarından çok kalitesine/örüntüsüne odaklanılması tıbbi beslenme tedavisinin esaslarını oluşturmaktadır.

Çıkar çatışması - Conflict of interest: Yazarlar çıkar çatışması olmadığını beyan ederler. - The authors declare that they have no conflict of interest.

\section{KAYNAKLAR}

1. American Diabetes Association. Lifestyle management: standards of medical care in diabetes-2019. Diabetes Care. 2019;42(Suppl. 1):S46-S60.

2. Kulkarni K, Castle G, Gregory R, Holmes A, Leontos C, Powers M, et al. The Diabetes Care and Education Dietetic Practice Group. Nutrition practice guidelines for type 1 diabetes mellitus positively affect dietitian practices and patient outcomes. J Am Diet Assoc. 1998;98:62-70.

3. Rossi MC, Nicolucci A, Di Bartolo P, Bruttomesso D, Girelli A, Ampudia FJ, et al. Diabetes Interactive Diary: a new telemedicine system enabling flexible diet and insulin therapy while improving quality of life: an open-label international, multicenter, randomized study. Diabetes Care. 2010;33:109-15.

4. Scavone G, Manto A, Pitocco D, Gagliardi L, Caputo S, Mancini L, et al. Effect of carbohydrate counting and medical nutritional therapy on glycaemic control in type 1 diabetic subjects: a pilot study. Diabet Med. 2010;27:477-9.

5. Franz MJ, MacLeod J, Evert A, Brown C, Gradwell E, Handu D, et al. Academy of Nutrition and Dietetics nutrition practice guideline for type 1 and type 2 diabetes in adults: systematic review of evidence for medical nutrition therapy effectiveness and recommendations for integration into the nutrition care process. J Acad Nutr Diet. 2017;117:1659-79.

6. UK Prospective Diabetes Study (UKPDS) Group. Effect of intensive blood-glucose control with metformin on complications in overweight patients with type 2 diabetes (UKPDS 34). Lancet. 1998;352:854-65.

7. Ziemer DC, Berkowitz KJ, Panayioto RM, El-Kebbi IM, Musey VC, Anderson LA, et al. A simple meal plan emphasizing healthy food choices is as effective as an exchange-based meal plan for urban African Americans with type 2 diabetes. Diabetes Care. 2003;26:1719-24.

8. Wolf AM, Conaway MR, Crowther JQ, Hazen KYL, Nadler J, Oneiba B, et al. Improving Control with Activity and Nutrition (ICAN) Study. Translating lifestyle intervention to practice in obese patients with type 2 diabetes: Improving Control with Activity and Nutrition (ICAN) study. Diabetes Care. 2004;27:1570-6. 
9. Coppell KJ, Kataoka M, Williams SM, Chisholm AW, Vorgers SM, Mann JI. Nutritional intervention in patients with type 2 diabetes who are hyperglycaemic despite optimised drug treatment-Lifestyle Over and Above Drugs in Diabetes (LOADD) study: randomised controlled trial. BMJ. 2010;341:c3337.

10. Pastors JG, Franz MJ. Effectiveness of medical nutrition therapy in diabetes. In: Franz MJ, Evert AB, eds. American Diabetes Association Guide to Nutrition Therapy for Diabetes. Alexandria, VA: American Diabetes Association. 2012;1-18.

11. Franz MJ. Diabetes Nutrition Therapy: Effectiveness, macronutrients, eating patterns and weight management. Am J Med Sci. 2016;351(4):374-9.

12. Gannon MC, Nuttall FQ. Effect of a high-protein, lowcarbohydrate diet on blood glucose control in people with type 2 diabetes. Diabetes. 2004;53(9):2375-82.

13. Monnier L, Colette C. Postprandial and basal hyperglycaemia in type 2 diabetes: Contributions to overall glucose exposure and diabetic complications. Diabetes Metab. 2015;41(6 Suppl 1):6S9-15.

14. Diyabet Diyetisyenliği Derneği. Diyabetin Önlenmesi ve Tedavisinde Kanıta Dayalı Beslenme Tedavisi Rehberi-2019. İstanbul; 2019.

15. Hockaday TDR. Should the diabetic diet be based on carbohydrate of fat restriction? In Turner M, Thomas B, editors. Nutrition and diabetes. London: Libbey; 1981. p. 23-32.

16. Hamdy O, Barakatun-Nisak MY. Nutrition in diabetes. Endocrinol Metab Clin North Am. 2016;45:799-817.

17. Feinman RD, Pogozelski WK, Astrup A, Bernstein RK, Fine EJ, Westman EC, et al. Dietary carbohydrate restriction as the first approach in diabetes management: critical review and evidence base. Nutrition. 2015;31(1):1-13.

18. Delahanty LM, Nathan DM, LachinJM, Hu FB, Cleary PA, Zieglar GK, et al. Diabetes Control and Complications Trial/Epidemiology of Diabetes. Association of diet with glycated hemoglobin during intensive treatment of type 1 diabetes in the Diabetes Control and Complications Trial. Am J Clin Nutr. 2009;89(2):518-24.

19. Xu J, Eilat-Adar S, Loria CM, Howard BW, Fabsitz RR, Beguum M, et al. Macronutrient intake and glycemic control in a population-based sample of American Indians with diabetes: the Strong Heart Study. Am J Clin Nutr. 2007;86:480-7.

20. Tay J, Luscombe-Marsh ND, Thompson $\mathrm{CH}$, Noakes M, Buckley JD, Wittert GA, et al. Comparison of lowand high- carbohydrate diets for type 2 diabetes management: a randomized trial. Am J Clin Nutr. 2015;102(4):780-90.

21. Koloverou E, Panagiotakos DB. Macronutrient Composition and Management of Non-insulin- dependent diabetes mellitus (NIDDM): A New paradigm for individualized nutritional therapy in diabetes patients. Rev Diabet Stud. 2016;13:6-16.

22. Boulé NG, Kenny GP, Haddad E, Wells GA, Sigal RJ. Metaanalysis of the effect of structured exercise training on cardiorespiratory fitness in type 2 diabetes mellitus. Diabetologia. 2003;46:1071-81.

23. Rejeski WJ, Ip EH, Bertoni AG, Bray GA, Evans G, Gregg EW, et al. Look AHEAD Research Group. Lifestyle change and mobility in obese adults with type 2 diabetes. $\mathrm{N}$ Engl J Med. 2012;366:1209-17.

24. Thomas DE, Elliott EJ. The use of low-glycaemic index diets in diabetes control. Br J Nutr. 2010;104:797-802.

25. Wheeler ML, Dunbar SA, Jaacks LM, KArmally W, Mayer-Davis EJ, Wylie-Rosett J, et al. Macronutrients, food groups, and eating patterns in the management of diabetes: a systematic review of the literature, 2010. Diabetes Care. 2012;35:434-45.

26. Thomas D, Elliott EJ. Low glycaemic index, or low glycaemic load, diets for diabetes mellitus. Cochrane Database Syst Rev 2009;1:CD006296.

27. Evert AB, Boucher JL, Dunbar SA, Cypress M, Franz MJ, Mayer-Davis EJ, et al. Nutrition Therapy Recommendations for the Management of Adults With Diabetes. Diabetes Care 2014; 37 (Suppl 1): S120-43.

28. Silva FM, Kramer CK, de Almeida JC, Steemburgo T, Gross JL, Azevedo MJ. Fiber intake and glycemic control in patients with type 2 diabetes mellitus: a systematic review with meta-analysis of randomized controlled trials. Nutr Rev. 2013;71:790-801.

29. Ley SH, Hamdy O, Mohan V, Hu FB. Prevention and management of type 2 diabetes: Dietary components and nutritional strategies. Lancet. 2014;383:1999-2007.

30. Franz MJ, Boucher JL, Evert AB. Evidence-based diabetes nutrition therapy recommendations are effective: the key is individualization. Diabetes Metab Syndr and Obes. 2014;7:65-72.

31. Hamdy O, Ganda, O, Maryniuk M, Gabbay R. CHAPTER 2. Clinical nutrition guideline for overweight and obese adults with type 2 diabetes (T2D) or prediabetes, or those at high risk for developing T2D. The American journal of managed care.2018; 24. SP226-SP231.

32. Diabetes Canada Clinical Practice Guidelines Expert Committee, Sievenpiper JL, Chan CB, Dworatzek PD, Freeze C, Williams SL. Nutrition Therapy. Can J Diabetes. 2018;42 Suppl 1:S64-S79.

33. He M, van Dam RM, Rimm E, Hu FB, Qi L. Whole grain, cereal fiber, bran, and germ intake and the risks of allcause and CVD-specific mortality among women with type 2 diabetes. Circulation. 2010;121(20):2162-8.

34. Melanson KJ, Zukley L, Lowndes J, Nguyen V, Angelopoulos TJ, Rippe JM. Effects of high-fructose corn 
syrup and sucrose consumption on circulating glucose, insulin, leptin, and ghrelin and on appetite in normalweight women. Nutrition. 2007;23:103-12.

35. Pan Y, Guo LL, Jin MJ. Low-protein diet for diabetic nephropathy: a meta- analysis of randomized controlled trials. Am J Clin Nutr. 2008;88:660-6.

36. Normand G, Lemoine S, Villien M, LEbars D, Merida İ, Írace Z, et al. AGE content of a protein load is responsible for renal performances: A Pilot Study Diabetes Care. 2018;41:1292-4.

37. Samkani A, Skytte MJ, KAndel D, Kjaer S, Astrup A, Deacon CF, et al. A carbohydrate-reduced high-protein diet acutely decreases postprandial and diurnal glucose excursions in type 2 diabetes patients. Br J Nutr.
2018;119:910-7.

38. Brehm BJ, Lattin BL, Summer SS, Boback JA, Gilchrist GM, Jandacek RJ, et al. One-year comparison of a highmonounsaturated fat diet with a high-carbohydrate diet in type 2 diabetes. Diabetes Care. 2009;32:215-20.

39. McEwen B, Morel-Kopp MC, Tofler G, Ward C Effect of omega-3 fish oil on cardiovascular risk in diabetes. Diabetes Educ. 2010;36:565-84.

40. Elhayany A, Lustman A, Abel R, Attal-Singer J Vinker S. A low carbohydrate Mediterranean diet improves cardiovascular risk factors and diabetes control among overweight patients with type 2 diabetes mellitus: a 1-year prospective randomized intervention study. Diabetes Obes Metab. 2010;12:204-9. 